\title{
BROKEN MAPS OF THE SEA
}

\section{Historylesson.}

$\mathrm{T}$ cient hunters. They carry their histories behind them, the broken hulls of sunken ships, the red-orange rust of harpoons, the twisted remains of old guns, pulled over sand and stone. Mist pours in behind them, ushering them across the village, as if some part of that world wants to follow them out.

As always, children stand behind the legs of parents, pointing at the giants' strange bodies, their slow, careful steps onto land. Others stand farther away and offer prayers, remembering the weight of that history, long before the days the giants grew legs and walked on land.

Now a song carries across the village.

"Do you know why those songs are called 'broken maps'?' he asks.

She hears them weaving in and out of single tones, diverging into high and low notes, as if tuning to each other.

"Because they use sound to guide themselves," she says. Yuko closes her eyes, trying to imagine the undersea world. "Like a map."

"They weren't just about maps; they were histories. But they were drowned by our machines. All our seismic surveys, the sonar systems of passing ships, blaring through the sea every day were like screams, breaking their patterns apart.

They approach the sand path, where a long winding road leads upward through the town, to a place Yuko has seen only from a distance.

"Millions of years before we came along, the oceans were filled with their histories."

She can see the parts of the old hunters' ships and weapons carefully assembled as they approach the temple, the remains that form the framework of its foundations.

"And then we came along and began to hunt them," Yuko says. "Why do they come back?"

"They come out of the sea to sing again, to remember their songs. And offer us a part of their memory."
As Yuko walks with her father, she hears a complex aria, a song that slowly surfaces in her mind. Other sounds play out beneath them, rhythms that are older than humankind. Soon, she will be among the memorybearers.

When they reach the top of the hill, the giants stop, their voices coursing through a familiar pattern. She had heard it many times in preparation for this day. But there are new patterns now, unfamiliar histories playing out between the notes. She tries to remember the lessons of her father, of everything he taught her about how to carry the songs in her mind.

The giants pull themselves out of the nets, carrying parts of the temple out, placing them against the wall of the structure for assembly. Their temple is finally beginning to take shape, a construction in the form of their ancient bodies, with a single long $\rightarrow$ NATURE.COM

Follow Futures: y @NatureFutures f go.nature.com/mtoodm tail, and a vast head turned up to the sky.

As she reaches the edge of the gathered giants, she follows the ritual path until she stands just below them.

Their heads are concealed in mist far above her tiny form, but she feels their thoughts already turning towards her. The world is a shifting terrain now, as if she is both here, on this Taiji hill, and somewhere far below the waves. She can feel her father standing next to her, helping her stand. "Stay with it," he says, but his voice is far away. She is somewhere beyond the shore, descending in long spirals. She feels herself choking, struggling to breathe, the music opening into patterns of motion and light. And then she is breathing from the borrowed lungs of a giant.

The farther down she goes, the more she falls inside the music, into a space far from the seaside village of her birth. She turns slowly, held by webs of sound that unspool like silk from their voices, weaving patterns that become maps and histories, and stories that she has never heard before.

Her father is kneeling next to her. There is a light at the edge of his eyes, crystalline, as if reflecting the patterns of the sea, a coral reef at the edge of a cave. She can still feel the giant, a ghost version of its body continuing beyond her own.

"You are now a memory-bearer," her father says, holding her up. Others gather around them, the giants turning their massive bodies to face them. She stares out at the fields beyond the temple and watches them change into a garden of coral. She feels the ghosts of other forms floating through depths she has never seen until now. A procession forms, opening into a line that leads to the temple and she walks towards it, preparing to tell them a story they have never heard before.

Preston Grassmann became a freelance writer after working as a regular reviewer for Locus Magazine. His most recent work has been published in AE: Canadian Science Fiction, Daily Science Fiction, Mythic Delirium and Slave Stories: Scenes From the Slave State. 